\title{
Implementation of IT Service Management Solutions in the University Environment Beyond the COVID-19 Pandemic: a SWOT Analysis
}

\author{
Liviu CIUCAN-RUSU ${ }^{1}$, \\ Marius-Petru POPTĂMAȘ ${ }^{1 *}$ \\ 1 "George Emil Palade" University of Medicine, Pharmacy, Sciences and Technology of Târgu Mureş, str. \\ Gheorghe Marinescu, number 38, Târgu Mureş, 540139, Romania
}

\begin{abstract}
The COVID-19 pandemic has imposed the acceleration of the digital transformation processes of organizations, regardless of the sector of activity. Moreover, currently, achieving sustainability indicators is particularly important, digitalization being an important step to minimize the social and environmental impact of organizations' activities. Our paper aims to identify the internal and external factors that influence the adoption of an IT Service Management solution during the pandemic in a public university in Romania that is in the process of transition to become a sustainable university.
\end{abstract}

Keywords: IT Service Management, SWOT analysis, university, organizational environment,COVID-19 pandemic, sustainability

JEL classification: I230; M120, M150

(C) 2021 Published by ACTA MARISIENSIS, SERIA OECONOMICA, Publisher University Press Târgu Mureș, issued on behalf of University of Medicine, Pharmacy, Sciences and Technology "George Emil Palade" from Târgu Mureş, Romania

\footnotetext{
* Author indicated for correspondence: Marius-Petru Poptămaş email: marius.poptamas@u2b.umfst.ro
} 


\section{INTRODUCTION}

In the context of the pandemic that appeared with the advent of the new coronavirus SARS$\mathrm{CoV}-2$, the usual circumstances have changed significantly, mobility has been reduced, units have temporarily closed their physical activity, online payment has been encouraged, etc. The use of public services cannot be suspended, but rather must be provided within a new framework that limits the spread of the virus, online, relying on quick solutions and the digital technology already available. Thus, there was an acute need to accelerate the digitization processes, but also to adapt the networks to the current needs. Among the organizational environments directly affected by the pandemic were also universities, the teaching activity being temporarily suspended, and then moved to the online environment for a long time. Considering this situation, there was an acute need to adapt, automate and digitize the organizational processes to the conditions imposed by the state of emergency, followed by the state of alert established at national level (President of Romania, 2020) So, the university education system underwent imminent changes, and the learning processes, but also the relations with students had to be quickly adapted to the new context. The first decision taken by the authorities regarding the health crisis was to prevent the spread of the killer virus, therefore, the measures taken were to restrict the movement of citizens, except in cases that represented an emergency. With this restriction, the remaining solutions have diminished, so that the step towards digitalization was imminent in all sectors of activity, the Romanian public sector being quite affected due to the existing digital infrastructure until the onset of the pandemic and the low level of digital skills held by the staff employed in this sector (CiucanRusu et al, 2021, Tocan et al, 2021; Noja \& Pânzaru, 2021).

The paper highlights the need to implement rapid solutions that respond to the new pandemic context by the "George Emil Palade" University of Medicine, Pharmacy, Sciences and Technology in Târgu Mureș, Romania (hereinafter referred to as UMFST). According to similar research (Agostino et al, 2021), we address three main issues in the provision of services: user involvement; planning and control; and costs. According to the mentioned study, these three elements are important and risk factors that influence the process of digital transformation of entities, as they highlight the problems that organizations will face in the future in the process of alignment with the needs of the market in a broad sense, not only in the pandemic context, but also in terms of environmental impact. Current economic, social and environmental challenges determine entities to adopt measures and behaviors that reduce their impact on society (Dănescu et al, 2021). Therefore, it is necessary to rethink the strategies, measures and procedures carried out by the university to reduce the environmental impact beyond the pandemic context, digitalization being an effective response to these environmental challenges.

Our study includes an analysis of the internal factors and external factors that can influence the decision to implement an information technology services management solution (ITSMs) in order to simplify the procedures for submitting social scholarship files within UMFST during the COVID-19 pandemic. The paper focuses in the first part on identifying the advantages of implementing ITSM solutions in the university, its connection with business process management (BPM), and in the second part of the paper we present an analysis of strengths, weaknesses, opportunities and threats (SWOT analysis) on the appropriateness and necessity of implementing such a solution. Our results have practical applicability, being communicated to the management in order to make decisions regarding the implementation of the proposed solution. The study represents an important step for automating other processes within the organization, as the proposed application is scalable, responding to several organizational problems. 


\section{THE LINK BETWEEN IT SERVICE MANAGEMENT AND BUSINESS PROCESS MANAGEMENT}

IT Service Management (ITSM) is represented by the planned and controlled use of both existing hardware and software components, as well as of human, material resources, in order to support the needs of employees and customers in an efficient manner (Galup et al, 2009).

According to IBM (ibm's website, accessed in March 2021), ITSM is composed of a set of policies and practices designed to help "deploy, provide, and manage IT services" in a way that meets all the needs of end users (represented by employees, customers, and other third parties) and the entity's goals. Through ITSM, entities ensure that all IT services are operating properly for the proper conduct of business. By IT services, we mean hardware and software components, but also computing resources existing in an organization, such as laptops, computers, software and web or mobile applications, cloud storage solutions or physical and virtual servers.

The term Business Process Management (BPM) is explained in detail, being dedicated to a web page https://bpm.com, and is defined as a discipline that involves different combinations of modeling, automation, execution, control, measurement, and optimization of business activity flows, facilitating the achievement of the enterprise's objectives and, at the same time, helping employees, customers, but also partners both inside and outside the organization.

Within the meaning of the European Business Process Management Association (AEBPM website, accessed in March 2021), BPM is represented as a systemic approach with the objective of capturing, designing, executing, documenting, measuring, monitoring and controlling both automated and non-automated processes in order to achieve the objectives related to the business strategy of a company.

On the one hand, Weske (2007) says that Business Process Management is based on the observation that each product supplied to the market by a company is the result of several activities carried out. On the other hand, in Gartner's opinion regarding BPM (Gartner website, accessed in March 2021), it is represented as a discipline that uses various methods to discover, model, analyze, measure, improve and optimize all the business processes in an organization.

IT Service Management offers process-based activities in terms of best practices to help it improve customer satisfaction, but it does not provide guidance or a specific methodology regarding the implementation of those processes and their daily management, so the BPM approach, which integrates all other initiatives of process-oriented improvement, is considered necessary.

From the above-mentioned considerations, the development and implementation of an ITSM solution is essential for the easing of organizational processes, regardless of the sector of activity. During the pandemic, there has been an acute pressure on the education and health sector to reorganize activities so as not to interrupt the provision of services related to these sectors (Neuwirth et al, 2021; Mishra et al, 2020; Haleem, \& Javaid, 2020). 


\section{RESEARCH METHODOLOGY}

Accelerating the digital transformation is induced by the pandemic is an opportunity for researchers and practitioners to observe and document how organizations are acting in a short period of time, providing important lessons for the future.

From an empirical point of view, this paper focuses in particular on an analysis of the need to implement an online application for enrollment of social scholarship files by UMFST students, a choice determined by several factors:

- the online-on-site (de)balance during the pandemic: in compliance with the conditions of social distancing, in the case of on-site submission of files, the secretariat of the faculties is overcrowded during the submission of files by students, increasing the risk of spreading the coronavirus, thus online submission becomes an optimal solution to avoid the spread of the epidemic;

- universities have the role of spreading an example in society, being the engine of local economic development. For this reason, the practices adopted by the university must have a minimal negative impact on society. The process of submitting social scholarship files on-site involves a relatively high consumption of material resources, with a negative impact on the environment. For this reason, by submitting the files online, the university contributes to the prevention of unwanted effects from a social and environmental point of view;

students can submit their files regardless of where they are located, while the secretariat and the evaluation committee will go through a simplified process of verification and evaluation of files due to the automation process that automatically recognizes the identification data of the depositor, the security and data protection being ensured both by its own maintenance team, as well as by the software provider, thus, increasing the usefulness, efficiency and level of satisfaction of the people involved in the process.

In the work it was aimed at reviewing the literature both to identify their concepts, definitions and area of application, as well as to identify internal or external factors that could influence the decision to implement such an online application. Also, at this stage, it was approached to prospecting many solutions in order to choose the optimal solution, for the responsibility of the purpose of the work. For this, the method of fundamental research was used. Then, based on fundamental research, we went through the development of a SWOT analysis, which highlights the main internal and external factors. The results of the SWOT analysis are summarized in Table 1 . These were debated by the research team, being taken into account in the process of elaboration, development and implementation of the proposed solution.

\section{RESULTS AND DISCUSSIONS}

In the following lines, we have represented a SWOT analysis (Table 1),through which we have brought to the surface the strengths, respectively the opportunities, which represent beneficial elements for achieving the objectives, together with the weaknesses, respectively the threats, representing characteristics that endanger the achievement of the proposed objectives. Both strengths and weaknesses are elements whose provenance is the internal source, while opportunities, along with threats are elements that come from the external source, which will help 
us better understand the usefulness of application integration, but also the benefits that come with it.

\section{Table 1. SWOT Analysis - The need to develop applications for IT Service Management in the organizational environment}

\begin{tabular}{|c|c|c|}
\hline & $\begin{array}{c}\text { Beneficial } \\
\text { achieving the objectives }\end{array}$ & $\begin{array}{c}\text { Endanger } \\
\text { achieving the objectives }\end{array}$ \\
\hline 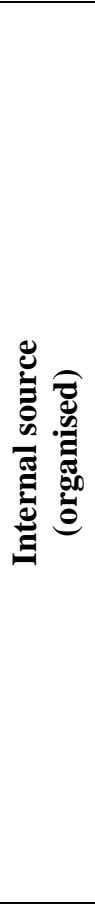 & $\begin{array}{l}\text { Strengths } \\
\text { - } \text { the existence of the necessary infrastructure } \\
\text { for the implementation of smart solutions; } \\
\text { - } \text { access to resources, thanks to existing } \\
\text { partnerships (Microsoft); } \\
\text { the existence of internal regulations and } \\
\text { procedures aimed at improving and } \\
\text { streamlining the relationship with students; } \\
\text { the existence of a friendly staff, oriented } \\
\text { towards solving the existing organizational } \\
\text { problems, especially in the relationship with } \\
\text { the students } \\
\text { the desire to simplify / eliminate bureaucracy; } \\
\text { encouraging and involving management in the } \\
\text { development, adaptation and implementation } \\
\text { of efficient digital solutions; } \\
\text { the high level of involvement of teachers in } \\
\text { attracting financial, material or human } \\
\text { resources for digitalization; } \\
\text { contribute to the achievement of the } \\
\text { university's sustainable development goals. }\end{array}$ & $\begin{array}{l}\text { Weaknesses } \\
\text { - deficit / lack of training in the digital } \\
\text { environment of the existing auxiliary staff; } \\
\text { the existence of a reluctance for } \\
\text { change/new; } \\
\text { lack of procedures regarding the way of } \\
\text { accessing /working the resources in the } \\
\text { Microsoft Office } 365 \text { suite; } \\
\text { reducing human interaction that can lead } \\
\text { both to damage to the psyche due to social } \\
\text { distancing and to creating confusions } \\
\text { about the procedures to be followed. }\end{array}$ \\
\hline 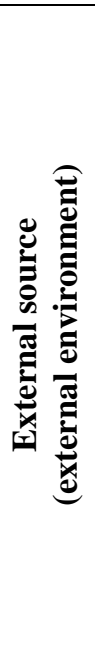 & $\begin{array}{l}\text { Opportunities } \\
\text { - } \text { accelerating the digitization processes, due to } \\
\text { the COVID-19 context; } \\
\text { the trend of automating work processes in } \\
\text { organizations - a trend found in EU strategies } \\
\text { on digitalization; } \\
\text { the existence of no-code / low-code } \\
\text { applications that are easy to implement, } \\
\text { without requiring intensive IT knowledge; } \\
\text { the existence of multiple sources of funding, } \\
\text { both national and European, for the } \\
\text { digitization of organizational environments, } \\
\text { being eligible also public institutions such as } \\
\text { state universities } \\
\text { low maintenance costs. }\end{array}$ & $\begin{array}{l}\text { Threats } \\
\text { - the possibility of receiving digital attacks } \\
\text { from outside; } \\
\text { - } \quad \text { students uploading erroneous information; } \\
\text { malfunction or malfunction of the } \\
\text { platform. }\end{array}$ \\
\hline
\end{tabular}

Source: authors' projection based on the research carried out 
Unlike other organizations, the great advantage of public institutions and especially of universities is the existence of a well-established information and communication technology (ICT) infrastructure, constituting one of the primary elements when considering the implementation of intelligent solutions. With the existence of infrastructure, the scope of opportunities widens, which leads to the encouragement of both students and teachers/ auxiliaries in the prototyping of new solutions designed to reduce the bureaucratic methodology, sometimes so bushy and cumbersome in terms of the fluidity of processes in the organization to the point of elimination / total replacement, and can also be considered a measure that respects the sustainable development indicators that the university has proposed.

In addition to access to infrastructure, another helping hand also comes from strategic partnerships at institutional level, thus facilitating access to software resources such as easy-toimplement "no-code/low-code" applications that do not require advanced IT knowledge, representing key elements throughout the digitization, respectively the automation of administrative processes and not only, that take place in the university's organizational environment.

Another element at least as crucial throughout this process is the level of involvement of teachers in attracting the financial, material or human resources necessary in the development process of ICT solutions for digitalization, a level that is as high as possible if we are to take a look at the total value of the projects attracted by them within UMFST.

Of course, any approach of the students or teachers involved cannot materialize unless the support from the management intervenes, which has a decision-making role in the implementation of new processes, both at the level of departments and at the institutional level, our university being advantaged from this point of view. Given the sustainable development strategy that the university has implemented, digitalization has become a key element in achieving sustainability goals.

With the implementation of new processes meant to solve the already existing problems and at the same time to ease the work of both parties (responsible / user), the emergence of reluctance for change / new, accompanied by the fear of ignorance, which is due to the lack of training in the digital environment of the existing teaching / auxiliary staff, intervenes. This fear can also be fueled by the possibility of receiving digital attacks from the outside or by the non-functioning or malfunctioning of the platform, situations that can occur involuntarily but can be prevented.

However, the university has the resources to counter any threats that may arise in the process of implementation, monitoring and sustainability of the proposed application. Considering that there are several advantages (strengths and opportunities) to support the positive opinion for the automation of organizational processes, the results of this study have public utility, and can be the foundation in the development of other ITSM solutions within our university and even at the level of other public institutions.

\section{CONCLUSIONS}

Following the SWOT analysis, it can be seen how the strengths, which are beneficial to the achievement of the objectives and come from the internal source, together with the opportunities coming from the external source, overcome the weak points that endanger the achievement of the objectives, along with the threats from the external source. Considering these aspects, one can 
highlight the need to implement an intelligent solution at university level, which comes to the aid of both students and auxiliary staff who take part in the process of submitting social scholarships.

This solution of digitizing the internal procedures for the submission and evaluation of social scholarships could be scaled to respond to multitudes of similar procedures, such as: submission of bachelor's, master's, doctoral papers, submission of personnel applications, enrollment in study programs or various extracurricular activities, etc. Our results can also be used by other organizations for the purpose of developing their own ITSM solutions.

From the present research it is found that there is a need to document the process of implementing the proposed solution. Taking into account the results of the study, the process of automating organizational processes in UMFST will continue, thus marking lessons for the future.

\section{ACKNOWLEDGEMENTS}

The team and resources of the development environment were supported within the Student Entrepreneurial Society project "Science in action for success in the era of business digitizationCNFIS-FDI-2021-0480".

\section{Bibliography}

Agostino, D., Arnaboldi,M. \& Diaz Lema, M. (2021) New development: COVID-19 as an accelerator of digital transformation in public service delivery, Public Money \& Management,41:1, 69-72, https://doi.org/10.1080/09540962.2020.1764206

Dănescu T, Spătăcean I-O, Popa M-A, Sîrbu C-G (2021). The Impact of Corporate Governance Mechanism over Financial Performance: Evidence from Romania. Sustainability, 13(19):10494. https://doi.org/10.3390/su131910494

Galup, S. D., Dattero, R., Quan, J. J., \& Conger, S. (2009). An overview of IT service management. Communications of the ACM, 52(5), 124. https://doi.org/10.1145/1506409.1506439

Haleem, A., \& Javaid, M. (2020). Medical 4.0 and its role in healthcare during COVID-19 pandemic: A review. Journal of Industrial Integration and Management. https://doi.org/10.1142/s2424862220300045

Mishra, D. L., Gupta, D. T., \& Shree, D. A. (2020). Online Teaching-Learning in Higher Education during Lockdown Period of COVID-19 Pandemic. International Journal of Educational Research Open, 100012. https://doi.org/10.1016/j.ijedro.2020.100012

Neuwirth LS, Jović S, Mukherji BR. (2021). Reimagining higher education during and postCOVID-19: Challenges and opportunities. Journal of Adult and Continuing Education. Vol. 27(2):141-156. https://doi.org/10.1177/1477971420947738.

Noja, G. \& Pânzaru, C. (2021). Five Possible Impacts of Digitalisation in Romania. European Review of Applied Sociology 2, Vol. 14(22), https://doi.org/10.1515/eras-2021-0001

President of Romania, DECREE no. 195 of 16 March 2020 on the establishment of the state of emergency on the territory of Romania, Published in the OFFICIAL GAZETTE no. 212 of March 16, 2020

Stew, M; Chindriş-Văsioiu, Cristea, A; Mărginean, I. (2021). Transforming Romania into a Knowledge Economy Through ICT - Current Developments. International Conference Knowledge-Based Organization, Vol. XXVII No 2, pp. 78-83, https://doi.org/10.2478/kbo-2021-0051 
Weske, M., (2007). Business Process Management Concepts, Languages, Architectures, Springer Publishing House, Berlin.

https://bpm.com , accessed in March 2021

https://www.gartner.com/en/information-technology/glossary/business-process-management-bpm, accessed in March 2021

https://www.ibm.com/cloud/learn/it-service-management, accessed in March 2021

http://www.eabpm.org/?page_id=5, accessed in March 2021 